Article

\title{
A Firm's Financial Reputation vs. Sustainability Reputation: Do Consumers Really Care?
}

\author{
Moritz Loock ${ }^{1}$ and Diane M. Phillips ${ }^{2, *}$ \\ 1 Department of Energy and Sustainability Management, Institute for Economy and the Environment, \\ University of St. Gallen, 9000 St. Gallen, Switzerland; moritz.loock@unisg.ch \\ 2 Department of Marketing, Saint Joseph's University, Philadelphia, PA 19131, USA \\ * Correspondence: dphillip@sju.edu
}

Received: 31 October 2020; Accepted: 8 December 2020; Published: 16 December 2020

check for updates

\begin{abstract}
In today's global marketplace, management teams spend a significant amount of effort on managing their organizations' image. Stellar reputations help to secure financing, attract business partners, and entice customers. Across two studies, we examine the extent to which a firm's financial and sustainability reputations are influenced by two distinct organizational activities: its status as a first mover in the field of sustainability and its chief executive officer's actions. We accomplish this by utilizing a basic semiotics framework to analyze the process by which a firm's reputation is created between the object (the firm), different signs (organizational activities), and an interpretant (the firm's reputation). Among other reported findings, we confirm that a firm's first mover status significantly impacts its financial reputation. In addition, the first mover status and the actions of its CEO both significantly impact the firm's sustainability reputation. In examining sustainability reputation more closely, we confirm a strong and significant effect of the firm's sustainability reputation on consumer attitudes toward the firm, which is mediated by the attitude toward the CEO and attitude toward the firm's first mover status. Do consumers care what organizations do? The answer is yes.
\end{abstract}

Keywords: semiotics; firm reputation; sustainability

\section{Introduction}

How does a consumer interpret and make sense of the myriad of news headlines and reports about corporate and chief executive officer (CEO) behavior? Importantly, do corporate and CEO behaviors really matter to customers? Many theories provide important insights on the mechanisms of how and why consumers form judgments about a firm's reputation. Oftentimes, however, these communications can be in conflict with one another. For instance, a car manufacturer may signal a strong commitment towards sustainability through its comprehensive sustainability report. However, the car manufacturer's product line can communicate a conflicting message if it produces a broad range of gas-guzzling vehicles. How is a sustainably-minded consumer to make sense of these often-conflicting messages? Within the context of sustainability, existing research does not provide clear guidance as to how consumers interpret the sustainability actions of a firm and use that information to develop conclusions about a firm's financial and sustainability reputation. Because a firm's reputation is not based on single and isolated cues, it is important to isolate the signs that are influential in helping consumers form those conclusions about a firm's reputation. Fundamentally, we have two primary research questions: first, how do consumers create perceptions of the dimensions of a firm's reputation (a firm's financial reputation vs. sustainability reputation)? Second, how do consumers perceive a firm's reputation from different and potentially conflicting signs (first mover actions vs. CEO actions)?

We proceed as follows. First, we review different dimensions of a firm's reputation and conclude that, within the realm of sustainability, the two most important dimensions of reputation are a 
firm's financial reputation and its sustainability reputation. Next, using a semiotics perspective, we hypothesize different effects from different highly-visible signs that an organization may enact. We report results from two experimental studies that help us understand how consumers create meaning from different cues. Our findings highlight important relationships and patterns. Our first finding of note is that a firm's first mover status significantly impacts its financial reputation. Second, the first mover status and the actions of its CEO both significantly impact the firm's sustainability reputation. In examining these relationships more closely, we found that first mover status and the actions of the CEO are distinct and separate constructs in the minds of consumers. Finally, we confirmed a strong and significant effect of the firm's sustainability reputation on consumer attitudes toward the firm, which is mediated by attitudes toward the CEO and attitudes toward the firm's first mover status. This study contributes to the extant and emerging literature on consumer perceptions of the sustainability actions of a firm. In doing so, we offer insights that further develop sustainability marketing theory and practice.

\section{A Firm's Reputation}

Management experts agree that a firm's reputation is an important asset to an organization and must be continually protected and nurtured by the management team [1,2]. A firm's reputation is a way to communicate important information to stakeholders about the firm's identity; what it is and what it stands for [3,4], as well as how it is distinct from the competition [4]. A strong positive reputation results in a stronger competitive advantage, better performance on the stock market, and enhanced financial performance [1]. Incidentally, in the US, CEOs who have a strong commitment to corporate social responsibility (CSR) are more likely to be women, to donate to the Democratic party, to be the subject of greater media scrutiny, and to lead private firms, as opposed to publicly owned firms [5].

There are also distinct disadvantages to an organization that breaks its reputational promise to stakeholders [4]. Indeed, the news media is full of reports about corporate scandals and CEOs misbehaving. Simply witness the downfall of such high-profile executives as Pappa John's CEO John Schnatter for making racist statements, Uber's co-founder and CEO Travis Kalanick for committing a string of PR missteps and creating a culture of sexism in the workplace [6], and CrossFit's CEO Greg Glassman for making disparaging comments about the Black Lives Matter movement [7]. These and other events have consumed management teams and stakeholders' attention for years after the offending events, and have resulted in the loss of revenue and business partners [8]. While these kinds of events may consume the business press, do consumers really care? Do these events influence a consumer's perceptions or evaluations of the firm?

A firm's reputation is thought to be built on a variety of factors, but two of the most important are its social/environmental reputation and its reputation as a reliable and financially strong company $[3,9,10]$. Therefore, our investigation focuses on two dimensions of a firm's reputation that seem particularly relevant to the economic, political, and health upheavals that are facing our planet today: A firm's financial reputation and a firm's sustainability reputation (see [3]).

\subsection{The Firm's Financial Reputation}

Our first area of focus centers on the importance of a firm's financial reputation. A firm's overall reputation and its financial reputation seem to go hand-in-hand. When a firm's overall reputation improves, so does its actual financial performance (cf., $[1,9,10])$. Much of this improved financial performance also inevitably influences financial reputation. Further, there is also an impact of the firm's financial reputation on its overall performance. A strong financial reputation can encourage investment in the corporation, provide access to lucrative contracts, encourage partnerships with other businesses, allow the company to charge higher prices, and encourage loyalty from customers [10]. 


\subsection{The Firm's Sustainability Reputation}

Overall reputation and sustainability reputation also seem to be closely tied to one another. Not only does a firm's good sustainability reputation encourage other like-minded business partners to seek business connections, but a firm's sustainability reputation is very important in consumer purchasing decisions, especially for sustainably-minded consumers. Seventy-nine percent of these consumers are concerned about an organization's sustainable manufacturing practices and $64 \%$ are concerned about transparency [11]. Although consumers agree that they need to change their own purchasing and consumption habits, a full $61 \%$ of them believe that corporations need to take the lead in tackling climate change [12] (p. 58). Further, more visible actions on the part of an organization often encourage external stakeholders to apply pressure for even more proactive environmental practices [13]. Eighty-eight percent of consumers in the US and the UK believe that brands should help them become more environmentally friendly and ethical in their daily lives [14]. For many consumers, a firm's sustainability-related actions seem to matter.

\section{What Is the Sustainable Consumer to Do?}

Consumers sometimes seem to have a hard time interpreting information and cues from organizations. So, although a vast majority of consumers prefer to be guided by organizations in their own sustainability journeys, $43 \%$ believe brands currently make it more difficult to be sustainable [14]. Some of this confusion is exacerbated by the tendency for some consumers to pay little attention to an organization's green initiatives $[15,16]$. Further, many organizations simply refrain from heavy promotion of those initiatives [16], for fear of being accused of greenwashing or simply because the management team believes it is disingenuous.

Adding to the difficulty in consumer perceptions is the potential for a perceptual gap between the firm's actual and perceived sustainability efforts. Indeed, there is often a significant gap between what stakeholders think about a firm's sustainability efforts and the firm's actual sustainability efforts. In one study, some fairly unsustainable companies were judged as sustainable, while some very sustainable companies were judged as being unsustainable [17]. It is no wonder that the relationships between the concepts of financial and sustainability performance seem so intertwined. We contend that financial and sustainability performance are not just strongly correlated with one another, they work synergistically with one another.

\section{Financial and Environmental Performance Are Connected}

The social/environment vs. economics dilemma is a false choice $[17,18]$. Regardless of what the media and political pundits often claim, organizations do not need to choose between doing what is right by the environment and doing what is right for the organization's financial health. Indeed, when the management team is clear about the possible tradeoffs, it is better able to develop strategies to simultaneously maximize social/environmental value and economic value $[19,20]$. First, it is clear that firms that have superior financial performance have the extra funds available to enact a variety of different sustainable measures [5]. However, the inverse is also clear: a focus on sustainability initiatives results in better financial performance. Financial performance is enhanced when the management team nurtures both its financial reputation and its social reputation [21]. Overall, organizations that have moved toward more sustainable operations have increased their profits [22], "enhanced their brands, and strengthened their competitive positions in the market" ([12], p. 58). These economically-based advantages are derived from the finding that there is greater volume and lower volatility in cash flows [23], as well as lower risk to a variety of external, sometimes unpredictable, pressures. Experts suggest that there are several distinct financial advantages for adopting a more sustainable approach to business operations [24]:

- Stay ahead of environmental regulations. The first important advantage to the organization is that it can stay ahead of environmental regulations [25]. Local, regional, and national governments 
around the world are enacting a variety of new environmental regulations. The organization that has already incorporated sustainable initiatives into its operations will be ahead of the competition and might even reap financial benefits (for example, by selling carbon credits).

- Lower costs. The second advantage is that the organization will significantly lower its costs. For example, the organization can save money in disposal fees if it recycles more, energy if it adds insulation and LED lighting, and raw materials costs if it is more judicious in using and reusing materials, as in the cradle-to-cradle design and production process [26].

- Become less susceptible to volatile energy prices. A third advantage is that the organization will be less susceptible to volatile energy prices if it lowers its overall dependence on energy derived from fossil fuels. Experts predict that energy prices will continue to remain volatile for the foreseeable future, as long as global oil supplies diminish, emerging markets ramp up their manufacturing capabilities, and oil producing countries continue to have political and economic upheavals [27].

- Be more innovative. The sustainable organization is more innovative in its approach to new products and new markets. Looking at the world through the lens of sustainability allows research and development $(R \& D)$ teams and decision-makers to develop solutions that they would not have previously considered.

- Attract and retain better talent. Another advantage is that the organization has the ability to attract and retain more talented, creative, and dedicated employees. Companies have found that sustainable operations expand the talent pool, while also increasing employee productivity and reducing attrition [28].

- Position the brand as a sustainable brand. Another critical economic advantage to more sustainable operations is that the organization can differentiate itself in the minds of important stakeholders, especially consumers. Not only does sustainability in retailing affect store choice [29], consumers seem to seek out brands that have sustainable characteristics. Indeed, one recent study found that brands that marketed their sustainability credentials grew 5.6 times faster than competitive brands [30].

\section{From a Semiotics Perspective}

How do consumers digest and interpret information about an organization? As organizations engage in an ongoing process of communicating their identity to outside observers [4], what meaning do consumers derive from the various communications and behaviors that an organization enacts? The study of semiotics offers useful insights into helping us understand how individuals understand the world around them. Semiotics is the science of understanding the structure and content of both verbal and nonverbal meaning [31]. Individuals interpret and make sense of a multitude of signs; a sign can be anything to which meaning can be attached, including a word, object, action, philosophy, image, or person [32]. Semiotics has been used to describe numerous issues regarding international management and marketing, including how information is created and derived about multinational corporations moving to a new culture [32], the reaction of consumers to different signs and symbols in advertising (cf., [33]), the underlying meaning related to everyday consumption practices (cf., [34]), and especially relevant to our work, the reaction of stakeholders to the listing of a firm on the Dow Jones Sustainability Index [23,35].

Perhaps the most widely used model for understanding semiotics is the one proposed by Peirce and described in detail by Mick $[31,36]$. There are three components of a semiotics triad: the object, the sign, and the interpretant. The object is the target that will be interpreted; the sign is some symbolic representation that is supposed to represent the object; and the interpretant is the unique meaning of the sign [31]. As an example, consider an advertisement for an exotic vacation destination. The object would be the island of Mallorca, the sign could be a depiction of blue skies, palm trees, and white sandy beaches, and the interpretant could be, "the good life." It is important to recognize that the interpretant is not the observer, but the observer's interpretation of the sign. 
As applied to business, semiotics has been a very useful model by which to describe how important cultural meanings move from the broader cultural context, to products and services, and finally to consumers [37]. Sometimes consumers form perceptions about the sustainability of a company based on a single sign, such as the size of a company. For example, compared to smaller companies, a large company is a signal that the firm is likely to have strong CSR programs [15]. Similarly, consumers interpret a company's position on the Dow Jones Sustainability Index as a signal that the firm has a strong sustainability reputation $[23,35]$.

Using concepts from semiotics, we attempt to analyze how consumers initially create meaning and how that meaning may be moved to other conceptual elements. Because a firm's reputation is built on the visible actions of the organization [1] and because an organization's first mover status and the behaviors of the CEO are two of the most visible dimensions of a firm's relationship with its customers and other stakeholders, we propose that these two factors will work together to help consumers form perceptions about the firm's reputation. We believe this approach can provide important insights as to how stakeholders interpret and understand the sometimes confusing and complex behaviors of organizations.

\subsection{First Mover Status}

Consumers may notice new products appear on store shelves or see news stories about new and/or innovative green products. Being a first mover in the realm of sustainability might be particularly beneficial to the organization's financial and sustainability reputation. Being the first organization to offer a new product or service can communicate important information to outside observers that the firm has a distinct advantage in the marketplace. In short, firms that enter first are more profitable and have higher market share than those who enter later [38]. These indicators of success are long-lasting and are very difficult to change [39]. Further, consumers who purchase from first mover organizations are likely to stay; the switching costs make them unlikely to leave and form a relationship with any new companies that might enter the market [39]. Consumers might also believe that organizations who are first movers might have a more sustainably-oriented value system; sustainability might simply be closer to their identity as an organization and sustainable actions on the part of the organization might be more authentic. Consumers often interpret signs of a firm's offering and make judgements about a firm's authenticity, which they then use in their evaluations of the firm (cf., [40]). Outdoor clothing manufacturer Patagonia, for example, was a first mover and is positioned as an organization that is authentic in its sustainability journey [41]. Within the realm of sustainable products and services, we believe that there should be an advantage such that perceptions of being a first mover will have a positive impact on perceptions of financial reputation and perceptions of sustainability reputation. That is,

Hypothesis 1 (H1). Compared to organizations that are later movers, organizations that are perceived to be first movers in sustainability will have increased perceptions of financial reputation.

Hypothesis 2 (H2). Compared to organizations that are later movers, organizations that are perceived to be first movers in sustainability will have increased perceptions of sustainability reputation.

\subsection{Actions of the Chief Executive Officer (CEO)}

CEO actions are also often the fodder of news stories, especially when those actions are particularly outrageous or distasteful. Given the ubiquitous news headlines of CEOs engaging in questionable practices, we sought to explore the impact of a CEO's personal behavior on the firm's financial and sustainability reputations. As the figurehead of the organization, a CEO's behavior is particularly important to setting a tone and strategy for an organization's performance. In contrast to previous research that argues that consumers often look the other way when a CEO's behavior is particularly 
egregious [42], we believe that the social media landscape of today makes it much less likely that consumers will easily forget and forgive misbehavior. When a CEO's private actions could potentially expose the firm to financial or reputational risk, those actions are certainly of interest to the board of directors, management team, and other stakeholders. Even if a CEO's actions may not implicate the organization itself, bad behavior is an unnecessary distraction for the firm and the management team [43] and can lead to a decrease in a firm's financial performance [9]. Indeed, the impact of such misbehavior on a firm's reputation can be significant and long lasting. On average, share prices decline by $3.1 \%$ immediately following news of misconduct and news stories persist for an average of five years after the misdeed. In addition, approximately one third of firms experience additional fallout after a CEO behaves badly, such as the loss of a major client, a lawsuit, or a federal investigation [43].

We expect that it will be important that the CEO actions fit with the organization's sustainability goals/vision and we expect that there will be a distinct advantage to the firm when the CEO is perceived to engage in sustainable behaviors. Specifically,

Hypothesis 3 (H3). Compared to organizations that have CEOs who do not behave sustainably, organizations that have CEOs that do behave sustainably will have increased perceptions of financial reputation.

Hypothesis 4 (H4). Compared to organizations that have CEOs who do not behave sustainably, organizations that have CEOs that do behave sustainably will have increased perceptions of sustainability reputation.

When these two very visible actions come together, we predict that there might also be an interaction effect between the first mover status and the actions of the CEO such that more favorable perceptions might be realized when the CEO, who is the architect of any first mover effort, is also engaging in sustainable activities. Such a situation might be viewed as more authentic or genuine by outside stakeholders and might even create expectations for further sustainable actions [44]. As a CEO and management team incorporate more sustainable measures into the firm's operations, sustainability becomes more of a core value for the organization. These forward-thinking decision-makers are much more strategic and commercial in their orientation, thus allowing them to out-maneuver the competition and better meet the needs of their consumers [45]. One set of researchers confirmed an interaction effect in a slightly different context; a firm's financial and social reputations work together to synergistically influence the financial performance of firms [21]. We thus propose a final set of hypotheses:

Hypothesis 5 (H5). A firm's first mover status and the sustainable actions of the CEO will interact to increase perceptions of financial reputation.

Hypothesis 6 (H6). A firm's first mover status and the sustainable actions of the CEO will interact to increase perceptions of sustainability reputation.

See Figure 1 below for a depiction of the proposed semiotics triad for our study.

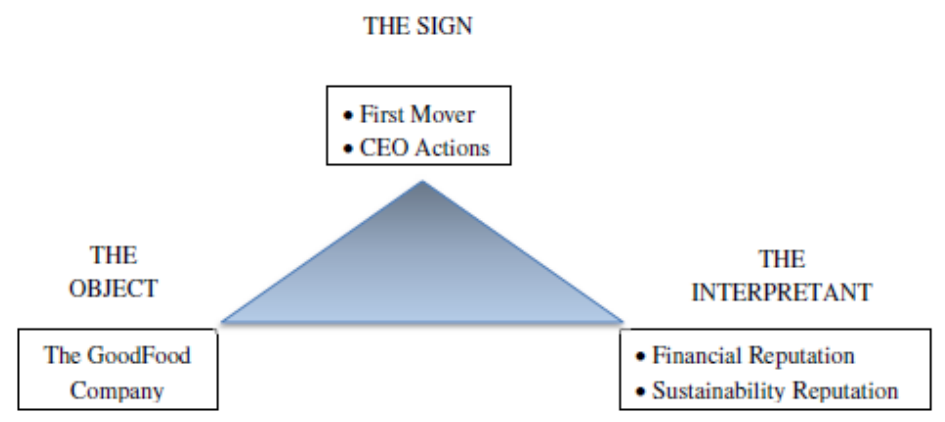

Figure 1. Sustainability semiotics triad. 


\section{Study 1}

\subsection{Method}

A 2 (first mover vs. late mover) X 2 (sustainable vs. non-sustainable CEO actions) between-subjects experiment was conducted.

\subsection{Procedure}

Participants were given one of four different "news stories" to read about a large European food retailer called GoodFood that had a "good value-good price" value proposition for its customers. To manipulate the first mover variable, participants read about how either the retailer was a first mover in sustainability or just recently moved into sustainability in the past five years. To manipulate the CEO actions variable, participants read about how the CEO was either an avid cyclist and recently rode the Tour de France course (sustainable action) or he loved motor sports and recently raced his car against a famous world champion racer in Bahrain (not sustainable action) (the use of news stories as a manipulation tool is widely-accepted in behavioral research, especially in communications and consumer behavior research (cf., [46-49])). Participants then filled out a brief series of scales on perceptions of financial reputation and sustainability reputation. Finally, they provided gender and age information.

\subsection{Results}

\subsubsection{About Our Participants}

A convenience sample of 62 graduate-level business students completed the study; $56.5 \%$ were male and $43.5 \%$ were female. Participants were recruited from a small liberal arts college in Switzerland and were not given any compensation for their participation. Their mean age was 24.8 years. The homogeneity of student samples makes them especially appropriate for a study like this where the goal is to explore and extend a theoretical concept (see, for example, [50-52]). Manipulation checks were conducted and confirmed the effectiveness of our manipulations.

\subsubsection{Development of Dependent Measures}

Financial reputation. In two separate studies of customer perceptions of corporate reputation, the following three items achieved the highest factor loadings and coefficient of determination scores [3]: tends to outperform competitors, seems to recognize and take advantage of market opportunities, and looks like it has strong prospects for future growth. These three items were combined to create an overall measure of financial reputation, which achieved an acceptable level of reliability (Cronbach $\alpha=0.621$ ).

Sustainability reputation. Similarly, the three items for sustainability reputation were derived from previous research which found, across two studies, that these items achieved high factor loadings and coefficient of determination scores [3]. The items were: would reduce its profits to ensure a clean environment, seems to be environmentally responsible, and appears to support good causes. As before, these three items were combined to create one overall sustainability reputation measure, which achieved an acceptable level of reliability (Cronbach $\alpha=0.627$ ). An examination of the bivariate correlations indicated that financial reputation and sustainability reputation were correlated with one another $(r=0.263, p<0.039)$.

\subsubsection{Financial Reputation}

An analysis of variance (ANOVA) was performed with financial reputation as the dependent variable and first mover status and CEO actions as the independent variables. The results indicated no main effects or interaction effects. Thus, perceptions of overall financial reputation are not impacted by 
whether or not the organization is a first mover or whether or not the CEO behaves in an environmentally responsible manner.

ANOVAs were then performed on each of the three individual items of financial reputation. Only the second item, "seems to recognize and take advantage of market opportunities" showed any significant effects. Specifically, although the overall effect was not significant, there was a marginally significant main effect of first mover status $\left(\mathrm{F}_{(1,58)}=3.85, p<0.055\right)$ which was most likely driven by perceptions of whether or not a firm seems to recognize and take advantage of market opportunities. This measure was higher when the firm was a first mover than when it was not (means $=5.03$ vs. 4.50 ). $\mathrm{H} 1$ was partially supported, but $\mathrm{H} 3$ was not supported. See Tables 1 and 2 below.

Table 1. Financial performance perceptions for early mover/late mover status.

\begin{tabular}{lccc}
\hline & Late Mover & Early Mover & Total \\
\hline Tends to outperform competitors & 4.27 & 4.56 & 4.42 \\
\hline $\begin{array}{l}\text { Seems to recognize and take advantage of } \\
\text { market opportunities }\end{array}$ & 4.50 & 5.03 & 4.77 \\
\hline Looks like it has strong prospects for future growth & 4.73 & 4.84 & 4.79 \\
\hline
\end{tabular}

Table 2. Financial performance perceptions for the actions of the chief executive officer (CEO).

\begin{tabular}{lccc}
\hline & $\begin{array}{c}\text { Non-Sustainable } \\
\text { Behaviors }\end{array}$ & $\begin{array}{c}\text { Sustainable } \\
\text { Behaviors }\end{array}$ & Total \\
\hline Tends to outperform competitors & 4.41 & 4.43 & 4.42 \\
\hline $\begin{array}{l}\text { Seems to recognize and take advantage of } \\
\text { market opportunities }\end{array}$ & 4.81 & 4.73 & 4.77 \\
\hline Looks like it has strong prospects for future growth & 4.88 & 4.70 & 4.79 \\
\hline
\end{tabular}

\subsubsection{Sustainability Reputation}

An ANOVA was performed with sustainability reputation as the dependent variable and first mover status and CEO actions as the independent variables. The results indicate only a main effect of the first mover status of the organization. The overall model was not significant, but the individual effect of first mover demonstrated marginal significance $\left(\mathrm{F}_{(1,58)}=3.86, p<0.054\right)$. Thus, when the firm was perceived as a first mover in sustainability, respondents believed that it was more likely to have a strong overall sustainability reputation (mean $=4.74$ vs. 4.29 ). Whether or not the CEO behaves in an environmentally responsible manner did not seem to matter in perceptions of sustainability reputation.

Next, we conducted three additional ANOVAs in order to examine each of the three individual sustainability reputation measures. Only the second item, seems to be environmentally responsible, showed any significant effects. Indeed, the overall model was significant $\left(\mathrm{F}_{(3,58)}=3.36, p<0.025\right.$, $\mathrm{R}^{2}$ adj $\left.=0.104\right)$ as were the individual effects of being a first mover $\left(\mathrm{F}_{(1,58)}=4.65, p<0.035\right)$ and the actions of the CEO $\left(\mathrm{F}_{(1,58)}=5.42, p<0.023\right)$. $\mathrm{H} 2$ is supported and $\mathrm{H} 4$ is partially supported. See Tables 3 and 4 below.

No significant interaction effects were found. Therefore, $\mathrm{H} 5$ and H6 were not supported; first mover status and CEO actions did not combine synergistically to impact financial reputation or sustainability reputation. Taken together, however, the results thus far indicated that there is a benefit in terms of more positive perceptions about the firm when it is perceived as a first mover in the field of sustainability and when the CEO's actions are environmentally friendly. 
Table 3. Sustainability performance perceptions for early mover/late mover status.

\begin{tabular}{lccc}
\hline & Late Mover & Early Mover & Total \\
\hline Would reduce its profits to ensure a clean environment & 3.37 & 3.78 & 3.58 \\
\hline Seems to be environmentally responsible & 4.67 & 5.28 & 4.98 \\
\hline Appears to support good causes & 4.83 & 5.16 & 5.00 \\
\hline
\end{tabular}

Table 4. Sustainability performance perceptions for the actions of the chief executive officer (CEO).

\begin{tabular}{lccc}
\hline & $\begin{array}{c}\text { Non-Sustainable } \\
\text { Behaviors }\end{array}$ & $\begin{array}{c}\text { Sustainable } \\
\text { Behaviors }\end{array}$ & Total \\
\hline Would reduce its profits to ensure a clean environment & 3.47 & 3.70 & 3.58 \\
\hline Seems to be environmentally responsible & 4.66 & 5.33 & 4.98 \\
\hline Appears to support good causes & 4.94 & 5.07 & 5.00 \\
\hline
\end{tabular}

Finally, in order to assess the simultaneous impacts of all of our constructs, our data were subjected to an structural equation modeling (SEM) analysis (the SEM analysis was performed using AMOS 24 by IBM SPSS). Because the first mover status and the CEO actions were not significantly correlated with one another, a covariate relationship was not specified in the model. Overall, the model was found to be significant $\left(\chi^{2}=32.2, \mathrm{df}=18\right)$, but the fit indices were only indicative of moderate fit (for example, NFI $=0.694$ and RMSEA $=0.114$ (for NFI (normed fit index), values above 0.95 are ideal and for RMSEA (root mean squared error of approximation), values below 0.05 are ideal [53]). An examination of the individual standardized effects revealed that a firm's sustainability reputation was significantly impacted by the firm's first mover status $(\beta=0.19)$ and the actions of the CEO $(\beta=0.25)$ while the firm's financial reputation was only significantly impacted by the firm's first mover status $(\beta=0.26)$ (see Figure 2 below). A summary of the results for Study 1 can be found in Table 5 below.

Table 5. Summary of results of effects on financial reputation and sustainability reputation.

\begin{tabular}{ll}
\hline \multicolumn{1}{c}{ Hypothesis } & \multicolumn{1}{c}{ Result } \\
\hline $\begin{array}{l}\text { H1: Compared to organizations that are later movers, organizations } \\
\text { that are perceived to be first movers in sustainability will have } \\
\text { increased perceptions of financial reputation. }\end{array}$ & $\begin{array}{l}\text { Partially supported with analysis of } \\
\text { variance (ANOVA) and supported in } \\
\text { structural equation modeling (SEM). }\end{array}$ \\
\hline $\begin{array}{l}\text { H2: Compared to organizations that are later movers, organizations } \\
\text { that are perceived to be first movers in sustainability will have } \\
\text { increased perceptions of sustainability reputation. }\end{array}$ & $\begin{array}{l}\text { Supported with ANOVA and SEM. } \\
\text { H3: Compared to organizations that have CEOs who do not behave } \\
\text { sustainably, organizations that have CEOs that do behave } \\
\text { sustainably will have increased perceptions of financial reputation. }\end{array}$ \\
$\begin{array}{l}\text { H4: Compared to organizations that have CEOs who do not behave } \\
\text { sustainably, organizations that have CEOs that do behave } \\
\text { sustainably will have increased perceptions of sustainability } \\
\text { reputation. }\end{array}$ & $\begin{array}{l}\text { Partially supported with ANOVA and } \\
\text { supported with SEM. }\end{array}$ \\
\hline $\begin{array}{l}\text { H5: A firm's first mover status and the sustainable actions of the } \\
\text { CEO will interact to increase perceptions of financial reputation. }\end{array}$ & Not supported. \\
\hline $\begin{array}{l}\text { H6: A firm's first mover status and the sustainable actions of the } \\
\text { CEO will interact to increase perceptions of sustainability reputation. }\end{array}$ & Not supported. \\
\hline
\end{tabular}




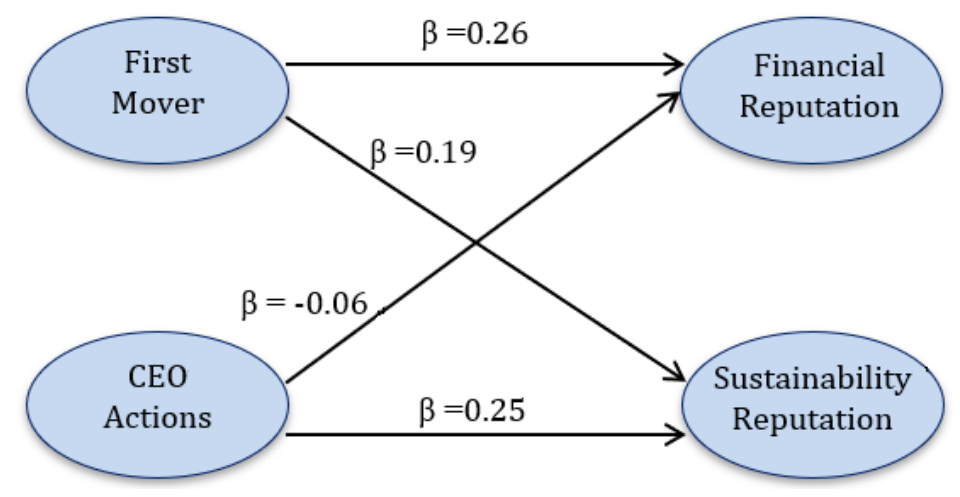

Figure 2. Effects of first mover status and CEO actions on financial reputation and sustainability reputation.

\subsection{Upon Reflection}

In ad hoc discussions with participants after the conclusion of the study, participants thought that what the CEO did on his own time was private and should not be of concern to any stakeholders. Upon reflection, we concluded that the manipulation for CEO actions may not have been strong enough. Further, individual item results for some of our measures in Study 1 provided some evidence that consumer attitudes might be influenced by a firm's first mover status and the CEO's actions. Study 2 was thus initiated to further explore some of our findings as well as the possibility that consumer attitudes may play a role in the process.

\section{Study 2}

\subsection{Method and Procedure}

The same basic $2 \times 2$ between-subjects experimental setup was utilized. This time, however, the manipulation of the CEO's sustainable vs. non-sustainable actions was much more heavy-handed. In the sustainable CEO conditions, participants read stories in which the CEO was an avid photographer and traveled to South America to shoot pictures of monkeys and orangutans. In the non-sustainable action condition, the CEO was an avid hunter and traveled to South America to shoot monkeys and orangutans with a gun.

\subsection{Results}

\subsubsection{About Our Participants}

A sample of 107 undergraduate-level business students completed the study in partial fulfilment of a course requirement; $41.1 \%$ were male and $57.9 \%$ were female (one person declined to answer this question). These participants were all matriculated students at a small liberal arts college in the US. Their mean age was 21 years. Manipulation checks were conducted and confirmed the effectiveness of our manipulations.

\subsubsection{Dependent Measures}

As with Study 1, we collected data for financial reputation and sustainability reputation. In addition, we added multiple-item measures for attitude toward being a first mover $\left(\mathrm{A}_{\text {mover }}\right)$, attitude toward the $\mathrm{CEO}\left(\mathrm{A}_{\mathrm{CEO}}\right)$, and attitude toward the firm $\left(\mathrm{A}_{\text {firm }}\right)$. All measures achieved very high levels of reliability (see Table 6 below). 
Table 6. Tests of reliability.

\begin{tabular}{lc}
\hline \multicolumn{1}{c}{ Variable } & Cronbach $\alpha$ \\
\hline Financial reputation & 0.808 \\
Environmental reputation & 0.885 \\
Attitude toward first mover status $\left(\mathrm{A}_{\text {mover }}\right)$ & 0.899 \\
Attitude toward the CEO $\left(\mathrm{A}_{\mathrm{CEO}}\right)$ & 0.927 \\
Attitude toward the firm $\left(\mathrm{A}_{\text {firm }}\right)$ & 0.924 \\
\hline
\end{tabular}

\subsubsection{Attitudes, First Mover Status, and CEO Actions}

Using a semiotics perspective, we sought to examine the extent to which the sign (first mover status and CEO actions) and the object (attitudes toward the firm) were related. A bi-variate, two-tailed correlational analysis revealed that the only strong and significant relationship between either of the signs (first mover status and $\mathrm{CEO}$ actions) and any of the three attitudes $\left(\mathrm{A}_{\text {mover }}, \mathrm{A}_{\mathrm{CEO}}\right.$, and $\left.\mathrm{A}_{\text {firm }}\right)$ was the strong and positive correlation between CEO actions and $\mathrm{A}_{\mathrm{CEO}}(r=0.384, p<0.0001)$.

\subsubsection{Financial and Sustainability Reputation}

In a confirmation of our contention that there is a relationship between a firm's financial and sustainability reputation, a bi-variate, two-tailed correlational analysis revealed the strong and significant relationship between the two $(r=0.461, p<0.0001)$. Financial reputation is also significantly correlated with $\mathrm{A}_{\text {mover }}(r=0.225, p<0.021)$, marginally correlated with $\mathrm{A}_{\mathrm{CEO}}(r=0.186, p<0.057)$, and significantly correlated with $\mathrm{A}_{\text {firm }}(r=0.383, p<0.0001)$. For sustainability reputation, the results are similar in that it is significantly correlated with $\mathrm{A}_{\text {mover }}(r=0.345, p<0.0001), \mathrm{A}_{\mathrm{CEO}}(r=0.436$, $p<0.0001)$, and $\mathrm{A}_{\text {firm }}(r=0.398, p<0.0001)$ (see Table 7 below for more details).

Table 7. Correlation Analysis *.

\begin{tabular}{cccccc}
\hline & $\begin{array}{c}\text { Financial } \\
\text { Reputation }\end{array}$ & $\begin{array}{c}\text { Sustainability } \\
\text { Reputation }\end{array}$ & $\mathbf{A}_{\text {mover }}$ & $\mathbf{A}_{\text {CEO }}$ & $\mathbf{A}_{\text {firm }}$ \\
\hline Financial & & & & \\
Reputation & & & & \\
\hline Sustainability & 0.461 & & & \\
Reputation & 0.0001 & 0.345 & & \\
\hline \multirow{2}{*}{$\mathrm{A}_{\text {mover }}$} & 0.225 & 0.0001 & 0.294 & \\
\hline \multirow{2}{*}{$\mathrm{A}_{\text {CEO }}$} & 0.021 & 0.436 & 0.002 & \\
\hline \multirow{2}{*}{$\mathrm{A}_{\text {firm }}$} & 0.186 & 0.0001 & 0.4961 & 0.0001 \\
\hline
\end{tabular}

* In the table above, the top number indicates the correlation estimate and the bottom number indicates the level of significance.

\subsubsection{Tests of Analysis of Variance (ANOVA)}

First, we performed an ANOVA in which first mover status and CEO actions were the independent variables and financial reputation was the dependent variable. There were no significant effects. Second, we ran the same model with sustainability reputation as the dependent variable. The overall model was not significant and the only significant effect was CEO actions, indicating a simple main effect $\left(\mathrm{F}_{(1,103)}=8.57, p<0.004\right)$. When a CEO's actions were sustainable, participants rated the firm's sustainability reputation as higher (5.24 vs. 4.66 , on a seven-point scale).

Diving deeper into the examination of attitudes, we performed three more sets of ANOVAs with our original two independent variables and each of the three attitudes: $A_{\text {mover }}, A_{C E O}$, and $A_{\text {firm }}$. The only significant effect occurred with $\mathrm{A}_{\mathrm{CEO}}$. The overall model was not significant, but the 
effect of CEO actions was significant, indicating a simple main effect $\left(\mathrm{F}_{(1,103)}=17.69, p<0.0001\right)$. Not surprisingly, the attitudes toward the CEO were lower when he engaged in especially bad behavior (means: 5.29 vs. 6.63 on a seven-point scale).

\subsubsection{Tests of Mediation}

A final set of analyses were performed to examine the extent to which the effect of financial reputation and sustainability reputation on $\mathrm{A}_{\text {firm }}$ may be mediated by either $\mathrm{A}_{\mathrm{CEO}}$ or $\mathrm{A}_{\text {mover }}$ (the process model (v. 3.5) by Andrew F. Hayes was utilized to conduct the mediation analyses). For each analysis, the following specifications were made to the model: model $4, C I=95$, and bootstrap iterations $=5000$.

The first set of analyses focused on financial reputation and the first analysis tested whether $\mathrm{A}_{\text {mover }}$ would be a mediator of the effect of financial reputation on $\mathrm{A}_{\text {firm }}$. Although the coefficients representing each of the relationships in the model were strong and positive, the total effect of financial reputation on $\mathrm{A}_{\text {firm }}$ was 0.6695 and the indirect effect was 0.4737 . This indicated that $70.75 \%$ of the total effect on $A_{\text {firm }}$ was a direct effect from financial reputation, leaving only $29.25 \%$ of the effect coming through the mediator $\left(\mathrm{A}_{\text {mover }}\right)$. The bootstrap results confirmed a nonsignificant effect of the mediator. The second analysis for financial reputation focused on $\mathrm{A}_{\mathrm{CEO}}$ as the mediator. The results were similar to the previous analysis. That is, although each of the proposed relationships indicated strong and positive coefficients, the total effect on $\mathrm{A}_{\text {firm }}$ still was mostly accounted for by financial reputation. That is, the total effect of financial reputation on $\mathrm{A}_{\text {firm }}$ was 0.6695 and the direct effect was 0.5292 , indicating that the direct effect was responsible for $79.04 \%$ of the total effect. This left the mediated $\mathrm{A}_{\mathrm{CEO}}$ relationship responsible for just $20.96 \%$ of the effect on $\mathrm{A}_{\text {firm }}$. Again, the bootstrap results indicated a nonsignificant effect of the mediator.

The pattern of results was quite different, however, for sustainability reputation. In the first analysis here, we examined the extent to which $\mathrm{A}_{\text {mover }}$ might be a mediator between sustainability reputation and $\mathrm{A}_{\text {firm }}$. All of the relationships specified were positive and significant, and the test of mediation indicated a significant effect of the mediator. Specifically, the total effects of sustainability reputation on $\mathrm{A}_{\text {firm }}$ were 0.4921 , while the direct effects were 0.2866 . This indicates that $58.24 \%$ of the effect on $\mathrm{A}_{\text {firm }}$ was directly from sustainability reputation and $41.76 \%$ was from the indirect mediated effect through $\mathrm{A}_{\text {mover }}$. An analysis of the $95 \%$ CI bootstrap confirmed a significant mediated effect through $\mathrm{A}_{\text {mover }}$. Next, we tested whether $\mathrm{A}_{\mathrm{CEO}}$ might be a mediator. The results were similar. Each of the proposed relationships resulted in positive and significant coefficients. The total effect of sustainability reputation on $\mathrm{A}_{\text {firm }}$ was 0.4921 and the direct effect was 0.2808 . This indicated that $57.06 \%$ of the total effect was due to sustainability reputation, but $42.94 \%$ was due to an indirect mediated effect through $\mathrm{A}_{\mathrm{CEO}}$. The post hoc bootstrap analysis confirmed a significant mediated effect (see Table 8 for a summary of the results).

Table 8. Results for mediation analyses *.

\begin{tabular}{|c|c|c|c|c|}
\hline & Coefficient & $p$-Value & Model $\mathbf{R}^{2}$ & Conclusion \\
\hline $\begin{array}{l}\text { Model 2: } A_{\text {CEO }} \text { as a } \\
\text { mediator between } \\
\text { FinRep and } A_{\text {firm }} \\
\text { FinRep } \rightarrow A_{\text {CEO }} \\
\text { FinRep } \rightarrow A_{\text {firm }} \\
A_{\text {CEO }} \rightarrow A_{\text {firm }}\end{array}$ & $\begin{array}{l}0.4310 \\
0.5292 \\
0.3255\end{array}$ & $\begin{array}{l}0.0566 \\
0.0004 \\
0.0000\end{array}$ & 0.1470 & $\begin{array}{l}\text { The direct effect accounts for } 79.04 \% \text { and the indirect } \\
\text { effect accounts for } 20.96 \% \text { of the total effect on } \mathrm{A}_{\text {firm }} \text {. } \\
\text { Bootstrap analysis indicates a nonsignificant effect. } \\
\text { Conclusion: } \mathrm{A}_{\mathrm{CEO}} \text { is not a significant mediator } \\
\text { between FinRep and } \mathrm{A}_{\text {firm }} \text {. }\end{array}$ \\
\hline
\end{tabular}


Table 8. Cont.

\begin{tabular}{|c|c|c|c|c|}
\hline & Coefficient & $p$-Value & Model $\mathbf{R}^{2}$ & Conclusion \\
\hline \multicolumn{5}{|l|}{ Model 3: $A_{\text {mover }}$ as a } \\
\hline 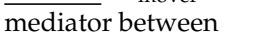 & & & & The direct effect accounts for $58.24 \%$ and the indirect \\
\hline SustRep $\rightarrow A_{\text {mover }}$ & 0.4335 & 0.0003 & & Bootstrap analysis indicates a significant effect. \\
\hline SustRep $\rightarrow \mathrm{A}_{\text {firm }}$ & 0.2866 & 0.0065 & & Conclusion: $\mathrm{A}_{\text {mover }}$ is a significant mediator \\
\hline$A_{\text {mover }} \rightarrow A_{\text {firm }}$ & 0.4742 & 0.0000 & 0.1582 & between SustRep and $\mathrm{A}_{\text {firm. }}$ \\
\hline \multicolumn{5}{|l|}{ Model 4: A CEO as a $_{\text {C }}$} \\
\hline$\overline{\text { mediator between }}$ & & & & The direct effect accounts for $57.06 \%$ and the indirect \\
\hline SustRep and $\mathrm{A}_{\text {firm }}$ & & & & effect accounts for $42.94 \%$ of the total effect on $A_{\text {firm }}$. \\
\hline SustRep $\rightarrow \mathrm{A}_{\mathrm{CEO}}$ & 0.7195 & 0.0000 & & Bootstrap analysis indicates a significant effect. \\
\hline SustRep $\rightarrow \mathrm{A}_{\text {firm }}$ & 0.2808 & 0.0156 & & Conclusion: $\mathrm{A}_{\mathrm{CEO}}$ is a significant mediator between \\
\hline $\mathrm{A}_{\mathrm{CEO}} \rightarrow \mathrm{A}_{\text {firm }}$ & 0.2937 & 0.0000 & 0.1582 & SustRep and $\mathrm{A}_{\text {firm }}$. \\
\hline
\end{tabular}

\subsection{From a Semiotics Perspective}

In examining Figure 2 again, our results confirm that viewing this phenomenon from a semiotics perspective is informative. First, the connection between the sign (first mover status and CEO actions) and the interpretant (financial reputation and environmental reputation) seems to be strong and significant in both studies. In particular, the SEM analysis in Study 1 establishes a strong relationship between these constructs, as does the correlational analysis in Study 2. Second, the connection between the interpretant (two reputations) and the object $\left(\mathrm{A}_{\text {firm }}\right)$ is also strong and significant. When the firm has a strong and positive financial reputation and sustainability reputation, there is a strong and positive attitude toward the firm. This connection was confirmed in Study 2 with the correlational analysis and the test of mediation. For financial reputation, we found a direct influence on $\mathrm{A}_{\text {firm }}$, whereas with sustainability reputation, we found a direct as well as an indirect influence on $A_{\text {firm }}$. Finally, the connection between the sign (first mover and CEO actions) and the object $\left(\mathrm{A}_{\text {firm }}\right)$ is somewhat more complicated. A correlational analysis in Study 2 reveals no significant relationship between these constructs. However, as discussed above, these two signs do have a significant effect on financial reputation and sustainability reputation, which in turn have a strong influence on $\mathrm{A}_{\text {firm }}$.

\section{Discussion}

The objective of this study was to examine the extent to which two distinct organizational activities, the firm's first mover status in sustainability and its CEO's actions, influenced consumer perceptions of that firm's financial and sustainability reputation. The first area of focus was a firm's financial reputation, or the extent to which consumers tend to believe that the firm efficiently and effectively handles its financial assets, and it is well-positioned to be financially successful in the future. Both studies confirmed that a firm's first mover status into the domain of sustainability significantly impacts its financial reputation, indicating that consumers view the firm's first mover status as an important sign of the firm's financial health and well-being. The second dimension of a firm's reputation was the firm's sustainability reputation. Here, both the first mover status and the actions of its CEO significantly impacted the firm's sustainability reputation. This indicates that consumers view both actions as important signs that sustainability is an important part of the value system and operating culture of the firm.

\section{Conclusions}

Consumers try to make sense of the world around them and often notice what firms and CEOs do. Two of a firm's most visible actions are its first mover status and the actions of its CEO. This study was designed to further our understanding of the way in which consumers perceive the visible actions of a firm. As issues of climate change and sustainability are being pushed to the forefront of our collective awareness, an important strength of this study is that it deepens our understanding of these very topical 
issues. We believe that this study has contributed to the theoretical understanding of how consumers form perceptions of a firm's financial and sustainability reputation. In that regard, we clarify how the visible actions of a firm influence consumer perceptions of financial and sustainability reputation, and how key constructs are related to one another.

\subsection{Consumer Perceptions of Financial and Sustainability Reputation}

The visible actions of the firm-its first mover status and the actions of its CEO-both independently influence a consumer's conclusions about the firm's financial and sustainability reputation. Specifically, a firm's first mover status significantly improved perceptions of financial reputation and sustainability reputation, while the sustainable actions of a firm's CEO significantly improved perceptions of a firm's sustainability reputation. Organizations should take heed of these findings. A strong financial reputation presents numerous performance benefits to the firm (cf., $[1,9,10])$ and a strong sustainability reputation is noticed and appreciated by sustainably-minded consumers (cf., [12,14]).

Diving deeper into the process by which consumers form perceptions of a firm's reputation, Study 2 demonstrated that consumer attitudes also play a key role in the process. When a CEO's actions were particularly egregious, consumer attitudes reflected their negative opinion of the CEO. Further, the mediational analyses reinforced the important mediational role of specific interim attitudes toward the signs ( $\mathrm{A}_{\text {mover }}$ and $\mathrm{A}_{\mathrm{CEO}}$ ) in the formation of more global attitudes toward the firm $\left(\mathrm{A}_{\text {firm }}\right)$. One thing is certain in our findings: consumers do indeed care about the firm's actions.

\subsection{Relationships of Key Constructs}

At the outset, we found that there was a strong correlation between a firm's financial and sustainability reputations. We believe that this relationship between these two dimensions of a firm's reputation will stir much debate and discussion in the next decade as senior-level executives attempt to determine how to manage their reputations. Questions regarding investment in sustainability initiatives, the introduction of new products, and the entry into new markets may hinge on the forecasted benefits to a firm's financial and sustainability reputations.

We were somewhat surprised by the finding that there were no synergistic effects in the form of an interaction effect between the firm's first mover status and the actions of the CEO on our two measures of reputation. In the consumer's mind, a firm's first mover status and the actions of its CEO each have separate and distinct influences on the firm's reputation, but have no relationship to one another. Not only were there no interaction effects, these constructs were not even correlated with one another. Further, this relationship did not change, regardless of whether the CEO's actions were mildly egregious or very egregious. This finding is quite intriguing because it indicates that consumers perceive these two constructs to be separate and distinct from one another. Management teams can thus be assured that there are at least two separate, direct pathways to building a more positive sustainability reputation: being a first mover and having a CEO that is very sustainable in his or her private life. Unfortunately, there is only one direct way to building a more positive financial reputation: being a first mover in the domain of sustainability. Of course, with the strong correlation between financial and sustainability reputation, both of these reputations represent an indirect path toward increasing the reputation of the other.

\subsection{Future Research}

One contribution of this study is the finding that a firm's first mover status increases perceptions of the firm's financial reputation. This should help address some of the criticisms that there are few financial benefits to sustainable initiatives. Although experts in the field of management strategy promote the financial benefits of social and environmental sustainability (cf. [19]), many managers and every-day citizens are still skeptical of its importance. One avenue for future research could be an investigation into the strong relationship between a firm's financial and sustainability reputations. 
When might one type of reputation become more influential in perceptions of a firm's overall performance? How might each reputation influence consumer purchasing behaviors? Which one might predominate when consumers are being targeted for relationship-building?

Another contribution that we make is to address the issue of a firm being a first mover in the realm of sustainability. Extensive previous research has been conducted on market entry strategies, but we are aware of no previous research that has addressed the issue of a firm's first foray into the domain of sustainability. Future research should further explore how firms who are first to market with a new sustainable product or service are viewed differently by different stakeholder groups. For example, is there an increase in perceptions that the firm is more genuine or authentic in its sustainability journey if it is first to market? How long do consumers remember a firm's entry into the market? How else might a firm signal its commitment to sustainability to stakeholders?

Overall, this investigation provides a better understanding of how consumers form perceptions about the firm's reputation. Semiotics has been widely utilized by other social sciences such as linguistics, sociology, ethnography, and history, and we were able to utilize it to better understand the process by which meaning is created and extended. We also found it useful to conceptually separate and identify the effects of this phenomenon. In addition, taking a semiotic perspective helped us utilize relevant methodology and theory to investigate this process. It also broadened the research agenda in the field of sustainability management and marketing by connecting it with other social science methods. It is informative for researchers to sample from a wide variety of methodologies as they build and strengthen their theories. Research interest in the area of sustainability and consumer behavior is growing and we are confident that significant contributions will continue to be made such that corporate performance will be more effectively aligned with the needs of consumers and the constraints of the natural environment.

Author Contributions: Conceptualization, M.L.; Methodology, M.L. and D.M.P.; Validation, M.L. and D.M.P.; Formal Analysis, D.M.P.; Data Curation, D.M.P.; Writing-Original Draft Preparation, D.M.P.; Writing-Review \& Editing, M.L. and D.M.P. All authors have read and agreed to the published version of the manuscript.

Funding: This research received no external funding.

Conflicts of Interest: The authors declare no conflict of interest.

\section{References}

1. Iwu-Egwuonwu, R.C. Corporate reputation \& firm performance: Empirical literature evidence. Int. J. Bus. Manag. 2011, 6, p197. [CrossRef]

2. Lii, Y.-S.; Lee, M. Doing right leads to doing well: When the type of CSR and reputation interact to affect consumer evaluations of the firm. J. Bus. Ethics 2012, 105, 69-81. [CrossRef]

3. Walsh, G.; Beatty, S.E. Customer-based corporate reputation of a service firm: Scale development and validation. J. Acad. Mark. Sci. 2007, 35, 127-143. [CrossRef]

4. King, B.G.; Whetten, D.A. Rethinking the relation between reputation and legitimacy: A social actor conceptualization. Corp. Reput. Rev. 2008, 11, 192-207. [CrossRef]

5. Borghesi, R.; Houston, J.F.; Naranjo, A. Corporate socially responsible investments: CEO altruism, reputation, and shareholder interests. J. Corp. Finance 2014, 26, 164-181. [CrossRef]

6. CNN Business. When Good Executives Go Bad. Video Production by CNN Business. 2019. Available online: https://www.cnn.com/2019/05/02/success/executives-behaving-badly/index.html (accessed on 31 October 2020).

7. Weng, P.-S.; Chen, W.-Y. Doing good or choosing well? Corporate reputation, CEO reputation, and corporate financial performance. N. Am. J. Econ. Finance 2017, 39, 223-240. [CrossRef]

8. Liu, X.; Vredenburg, H.; Steel, P. Exploring the mechanisms of corporate reputation and financial performance: A meta-analysis. In Academy of Management Proceedings; Academy of Management: Briarcliff Manor, NY, USA, 2019; Volume 2019, p. 17903.

9. McEvoy, J. Every CEO and Leader that Stepped Down Since Black Lives Matter Protests Began. 2020. Available online: https://www.forbes.com/sites/jemimamcevoy/2020/07/01/every-ceo-and-leader-thatstepped-down-since-black-lives-matter-protests-began/\#5cbca2dc5593 (accessed on 25 October 2020). 
10. Larcker, D.; Tayan, B. We studied 38 incidents of CEO bad behavior and measured their consequences. Harv. Bus. Rev. 2016, 9.

11. Grail Research. The Green Evolution. A Research Report by Grail Research; LLC, an Integreon Company: Oakland, CA, USA, 2011.

12. Bonini, S.; Oppenheim, J. Cultivating the green consumer. Stanf. Soc. Innov. Rev. 2008, 6, 56-61.

13. Townsend, S. 88\% of Consumers Want You to Help Them Make a Difference. 2018. Available online: https://www.forbes.com/sites/solitairetownsend/2018/11/21/consumers-want-you-to-help-themmake-a-difference/\#5d3f41fd6954 (accessed on 26 October 2020).

14. Green, T.; Peloza, J. How do consumers infer corporate social responsibility? The role of organisation size. J. Consum. Behav. 2014, 13, 282-293. [CrossRef]

15. Conick, H. How Brands Can Help Consumers Green Up Their Act. Marketing News, a Publication of the American Marketing Association. 2019. Available online: https://www.ama.org/marketing-news/howbrands-can-help-consumers-green-up-their-act/ (accessed on 26 October 2020).

16. Peloza, J.; Loock, M.; Cerruti, J.; Muyot, M. Sustainability: How stakeholder perceptions differ from corporate reality. Calif. Manag. Rev. 2012, 55, 74-97. [CrossRef]

17. Ferron-Vilchez, V.; Darnall, N.; Aragon-Correa, J.A. Stakeholders' Influences on the Comprehensiveness and Visibility of Facilities' Proactive Environmental Practices; Working Paper; The Economics and Business School at the University of Granada: Granada, Spain, 2012.

18. Hahn, T.; Figge, F.; Pinkse, J.; Preuss, L. Trade-offs in corporate sustainability: You can't have your cake and eat it. Bus. Strat. Environ. 2010, 19, 217-229. [CrossRef]

19. Salonen, A.A.; Camilleri, M.A. Creating shared value. SSRN Electron. J. 2020, 89, 1-2. [CrossRef]

20. Figge, F.; Hahn, T. Is green and profitable sustainable? Assessing the trade-off between economic and environmental aspects. Int. J. Prod. Econ. 2012, 140, 92-102. [CrossRef]

21. Martinez, A.D.; Russell, Z.A.; Maher, L.P.; Brandon-Lai, S.A.; Ferris, G.R. The sociopolitical implications of firm reputation. J. Leadersh. Organ. Stud. 2016, 24, 55-64. [CrossRef]

22. Boakye, D.J.; Tingbani, I.; Ahinful, G.; Damoah, I.; Tauringana, V. Sustainable environmental practices and financial performance: Evidence from listed small and medium-sized enterprise in the United Kingdom. Bus. Strat. Environ. 2020, 29, 2583-2602. [CrossRef]

23. Lourenço, I.C.; Callen, J.L.; Branco, M.C.; Curto, J.D. The value relevance of reputation for sustainability leadership. J. Bus. Ethics 2014, 119, 17-28. [CrossRef]

24. Phillips, D.M.; Phillips, J.K. We'd like our clothes back please! Partnering with consumers to achieve sustainability goals. In The Palgrave Handbook of Sustainability; Springer Science and Business Media LLC: New York, NY, USA, 2018; pp. 599-614.

25. Martin, D.; Schouten, J. Sustainable Marketing; Prentice Hall: Boston, MA, USA, 2012.

26. McDonough, W.; Braungart, M. Cradle to Cradle: Remaking the Way We Make Things, 1st ed.; North Point Press: New York, NY, USA, 2002.

27. Friedman, T.L. Hot, Flat, and Crowded: Why We Need a Green Revolution-And How it Can. Renew. America, Release 2.0, Updated and Expanded; Picador: New York, NY, USA, 2009.

28. Peretz, M. Attract and Retain Millennials by Making This Commitment. Available online: https://www.forbes.com/sites/marissaperetz/2017/11/08/attract-and-retain-millennials-by-making-thiscommitment/\#52450e1a1163 (accessed on 28 October 2020).

29. Hampl, N.; Loock, M. Sustainable development in retailing: What is the impact on store choice? Bus. Strat. Environ. 2012, 22, 202-216. [CrossRef]

30. Whelan, T.; Kronathal-Sacco, R. Research: Actually, consumers do buy sustainable products. Harv. Bus. Rev. Digit. Articles 2019, 2-4.

31. Mick, D.G. Consumer research and semiotics: Exploring the morphology of signs, symbols, and significance. J. Consum. Res. 1986, 13, 196-213. [CrossRef]

32. Brannen, M.Y. When Mickey loses face: Recontextualization, semantic fit, and the semiotics of foreignness. Acad. Manag. Rev. 2004, 29, 593-616. [CrossRef]

33. DeRosia, E.D. The effectiveness of nonverbal symbolic signs and metaphors in advertisements: An experimental inquiry. Psychol. Mark. 2008, 25, 298-316. [CrossRef]

34. Ogilvie, M.; Mizerski, K. Using semiotics in consumer research to understand everyday phenomena. Int. J. Mark. Res. 2011, 53, 651-668. [CrossRef] 
35. Robinson, M.J.; Kleffner, A.; Bertels, S. Signaling sustainability leadership: Empirical evidence of the value of DJSI membership. J. Bus. Ethics 2011, 101, 493-505. [CrossRef]

36. Mick, D.G.; Burroughs, J.E.; Hetzel, P.; Brannen, M.Y. Pursuing the meaning of meaning in the commercial world: An international review of marketing and consumer research founded on semiotics. Semiotica 2004, 2004, 1-74. [CrossRef]

37. McCracken, G. Culture and consumption: A theoretical account of the structure and movement of the cultural meaning of consumer goods. J. Consum. Res. 1986, 13, 71-84. [CrossRef]

38. Gómez, J.; Maícas, J.P. Do switching costs mediate the relationship between entry timing and performance? Strat. Manag. J. 2011, 32, 1251-1269. [CrossRef]

39. Bolton, L.E.; Heath, C. Believing in First Mover Advantage; The Wharton School, University Isin Guler. An Empirical Examination of Aggregate Patterns of US Venture Capital Decision Making. 2007. Available online: https://faculty.wharton.upenn.edu/wp-content/uploads/2007/01/Believing_in_first_mover_ advantage_3.pdf (accessed on 16 December 2020).

40. Grayson, K.; Martinec, R. Consumer perceptions of iconicity and indexicality and their influence on assessments of authentic market offerings. J. Consum. Res. 2004, 31, 296-312. [CrossRef]

41. Chouinard, Y. Let My People Go Surfing: The Education of a Reluctant Businessman; The Penguin Group: New York, NY, USA, 2006.

42. Bhattacharjee, A.; Berman, J.Z.; Reed, A. Tip of the hat, wag of the finger: How moral decoupling enables consumers to admire and admonish. J. Consum. Res. 2013, 39, 1167-1184. [CrossRef]

43. Larcker, D.; Tayan, B. When a CEO's Personal Life Should Be Made Public: Here Are Guidelines for Directors Who Have to Make That Tricky Call; The Wall Street Journal: New York, NY, USA, 2019.

44. Globescan Sustainability. Companies and Governments Lag NGOs in Driving Sustainability but New Corporate Leaders Are Emerging, According to Experts, The Sustainability Survey. 2009. Available online: https://www.csrwire.com/press_releases/27377-companies-and-governments-lag-ngos-in-drivingsustainability-but-new-corporate-leaders-emerging-according-to-experts (accessed on 31 October 2020).

45. Lueneburger, C.; Goleman, D. The change leadership sustainability demands. MIT Sloan Manag. Rev. 2010, 51, 49-55.

46. Chen, Z.; Berger, J. How content acquisition method affects word of mouth. J. Consum. Res. 2016, 43, 86-102. [CrossRef]

47. Hoewe, J. Coverage of a crisis: The effects of international news portrayals of refugees and misuse of the term "immigrant". Am. Behav. Sci. 2018, 62, 478-492. [CrossRef]

48. Jin, H.S. Compounding consumer interest: Effects of advertising campaign publicity on the ability to recall subsequent advertisements. J. Advert. 2013, 32, 29-41. [CrossRef]

49. Kleemans, M.; Vettehen, P.G.J.H.; Beentjes, J.W.J.; Eisinga, R. The influence of age and gender on preferences for negative content and tabloid packaging in television news stories. Commun. Res. 2011, 39, 679-697. [CrossRef]

50. Calder, B.J.; Phillips, L.W.; Tybout, A.M. Designing research for application. J. Consum. Res. 1981, 8, $197-207$. [CrossRef]

51. Calder, B.J.; Phillips, L.W.; Tybout, A.M. Beyond external validity. J. Consum. Res. 1983, 10, $112-114$. [CrossRef]

52. Ashraf, R.; Merunka, D. The use and misuse of student samples: An empirical investigation of European marketing research. J. Consum. Behav. 2017, 16, 295-308. [CrossRef]

53. Blunch, N. Introduction to Structural Equation Modelling Using SPSS and AMOS; SAGE Publications: Newbury Park, CA, USA, 2008.

Publisher's Note: MDPI stays neutral with regard to jurisdictional claims in published maps and institutional affiliations. 